\title{
Financial markets and the allocation of capital ${ }^{\text {is }}$
}

\author{
Jeffrey Wurgler*
}

Yale School of Management, Box 208200, New Haven, CT 06520-8200, USA

Received 11 June 1999; received in revised form 30 September 1999

\begin{abstract}
Financial markets appear to improve the allocation of capital. Across 65 countries, those with developed financial sectors increase investment more in their growing industries, and decrease investment more in their declining industries, than those with undeveloped financial sectors. The efficiency of capital allocation is negatively correlated with the extent of state ownership in the economy, positively correlated with the amount of firm-specific information in domestic stock returns, and positively correlated with the legal protection of minority investors. In particular, strong minority investor rights appear to curb overinvestment in declining industries. (C) 2000 Elsevier Science S.A. All rights reserved.
\end{abstract}

JEL classification: G15; G31; D92

Keywords: Capital allocation; Investment; Economic growth; State ownership

I would like to thank Alexandre Aganine, Andrew Bernard, Marianne Bertrand, Richard Caves, Christopher Foote, Peter Henry, Dirk Jenter, G. Andrew Karolyi, Vassil Konstantinov, Rafael La Porta, Ross Levine, Ellen Meara, Miguel Messmacher, Michael Milken, Serkan Savasoglu, David Scharfstein, René Stulz, Jake Vigdor, Katia Zhuravskaya, an anonymous referee, seminar participants at Boston University, Harvard University, London Business School, the National Bureau of Economic Research, Stanford University, The Ohio State University, the University of Chicago, the University of North Carolina at Chapel Hill, and Yale University, and especially Malcolm Baker, John Campbell, Paul Gompers, and Andrei Shleifer for helpful comments. This study has been supported by the Division of Research of the Harvard Graduate School of Business Administration and by a prize from the Milken Institute.

* Tel.: + 1-203-432-6309; fax: + 1-203-432-8931.

E-mail address: jeffrey.wurgler@yale.edu (J. Wurgler). 
Political economists say that capital sets towards the most profitable trades, and that it rapidly leaves the less profitable non-paying trades. But in ordinary countries this is a slow process.... In England, however, ... capital runs as surely and instantly where it is most wanted, and where there is most to be made of it, as water runs to find its level.

Bagehot (1873), as quoted by Levine (1997, p. 695)

\section{Introduction}

A fundamental job of the economy is to allocate capital efficiently. To achieve this, capital is supposed to be invested in the sectors that are expected to have high returns and be withdrawn from sectors with poor prospects.

For a long time and for many reasons, economists have suspected that formal financial markets and associated institutions improve the capital allocation process and thus contribute to economic growth. One popular theory is that efficient secondary market prices help investors distinguish good investments from bad ones through a mechanism like Tobin's Q. Another is that lenders and intermediaries screen out bad projects (Bagehot, 1873; Schumpeter, 1912; Diamond, 1984; Boyd and Prescott, 1986). Agency theories argue that pressures from external investors, as well as managerial ownership, encourage managers to pursue value-maximizing investment policies (Jensen, 1986); in turn, effective laws against misuse of minority investors' funds determine the supply of finance to good projects (La Porta et al., 1997).

Despite this body of theory, there is little direct evidence on whether and how financial markets improve the allocation of capital. This paper takes a step toward filling the gap. The basic data set is a 65-country, 28-industry, 33-year panel of gross capital formation (investment) and value added (sales minus cost of intermediate goods). The main finding is that developed financial markets, as measured by the size of the domestic stock and credit markets relative to GDP, are associated with a better allocation of capital. Financially developed countries increase investment more in their growing industries and decrease investment more in their declining industries. Thus, although financially developed countries might not invest at a higher level (Carlin and Mayer, 1998; Beck et al., 2000), they do seem to allocate their investment better.

For example, the elasticity of industry investment to value added is several times higher in Germany, Japan, the United Kingdom, and the U.S. than in financially undeveloped countries such as Bangladesh, India, Panama, and Turkey. Relative to countries with large financial markets, other countries both overinvest in their declining industries and underinvest in their growing industries. Since value added growth is reliably positively correlated with Tobin's Q (which, unfortunately, cannot be constructed for a wide range of 
countries and industries), this result suggests that financial development helps a country take better advantage of its investment opportunities. Thus, financial markets and institutions do more than just provide a sideshow to the real economy; they perform a fundamental allocative function. And although financial market variables are not able to explain all of the cross-country variation in the quality of capital allocation, they are able to explain a substantial proportion.

I find evidence that capital allocation is improved through at least three mechanisms. First, countries with stock markets that impound more firmspecific information into individual stock prices - those that have less stock price "synchronicity" as measured by Morck et al. (2000) - exhibit a better allocation of capital. This is consistent with the suggestion that larger markets have more informative prices (perhaps due to more effective arbitrage facilitated by liquidity and low transaction costs) which help investors and managers distinguish between good and bad investments through more accurate measures of Q.

Second, capital allocation improves as state ownership declines. Countries with extensive state ownership do not increase investment much in growing industries and do not decrease it much in declining industries. This is not surprising since, in state-owned firms, resource allocation is likely to be guided less by value-maximization than by political motives; moreover, soft budget constraints and poor monitoring give managers in state-owned firms few incentives for efficiency. The evidence here supports Shleifer's (1998, p. 144) view that "elimination of politically motivated resource allocation has unquestionably been the principal benefit of privatization around the world."

Third, strong minority investor rights, as measured by La Porta et al. (1998), are associated with better capital allocation. The allocational benefit of investor rights seems to come through limiting overinvestment in declining industries rather than through improving the supply of finance to growing industries. This result can be explained by Jensen's (1986) free cash flow theory in that cash generated from operations is being inefficiently reinvested in declining industries, particularly in countries where minority investors are not in a position to object.

This paper complements an emerging literature that studies the relationship between finance and economic growth. At the country level, King and Levine (1993), Levine (1998), Levine and Zervos (1998), and Beck et al. (2000) make an empirical case that financial development causes growth. At the industry level, Rajan and Zingales (1998) show that the same industries that rely on external financing in the US - arguably, industries with a technological need for external finance, perhaps to reach an efficient scale - grow faster in financially developed countries. At the U.S. state level, Jayaratne and Strahan (1996) find that economic growth increases in states that relax intrastate bank branching restrictions. At the firm level, Demirguc-Kunt and Maksimovic (1998) use a financial 
planning model to estimate sustainable growth rates in the absence of external finance and find that firms in financially developed countries are able to grow faster than this benchmark.

Is better capital allocation a reason why financial development is associated with economic growth? Several authors have suggested this, including Goldsmith (1969), McKinnon (1973), Shaw (1973), and Greenwood and Jovanovic (1990). This suggestion is supported by some empirical evidence, both anecdotal and systematic. Bagehot (1873) cites better capital allocation as a primary reason for England's comparatively fast growth in the mid-to-late 19th century. Jayaratne and Strahan provide evidence that their U.S. state-level results reflect improvements in the quality of banks' loan portfolios, i.e., improvements in the allocation of their capital. Also, in their cross-country study, Beck et al. infer that the link between finance and growth is improved allocational efficiency, as suggested by the fact that financial development (specifically, the banking sector) is robustly associated not with higher capital accumulation but rather with higher productivity growth, which is how an improvement in capital allocation is expressed in their growth accounting framework.

The results of this paper do not support the rationale for securities transactions taxes given by Keynes (1936) and Summers and Summers (1989); Schwert and Seguin (1993) survey this literature. Advocates of securities transaction taxes typically argue that such taxes would throw enough "sand into the gears" to remove some of the purely speculative interests from financial markets and leave the real, allocative interests to work unfettered. The results here, however, suggest that less sand is always better. The most liquid financial markets in the world are also the ones that allocate capital most efficiently.

The paper proceeds as follows. Section 2 discusses data and methodology. Section 3 estimates the efficiency of capital allocation for 65 countries and uncovers some financial determinants of these estimates. Section 4 concludes.

\section{Data and methodology}

Because I am interested in comparing the efficiency of capital allocation across a broad range of financial systems, the availability of comparable international data is a significant constraint. In this section I first describe the data and methodology that will be used to calculate country-specific estimates of the efficiency of capital allocation and then the financial system data that will be used to explore the determinants of these estimates.

\subsection{International manufacturing industry statistics}

I use the United Nations' General Industrial Statistics panel (the INDSTAT-3 $\mathrm{CD}-\mathrm{ROM}$ ) as a source of basic manufacturing statistics. It reports gross fixed 
capital formation, value added, and output for up to 28 three-digit ISIC manufacturing industries (an international classification standard that corresponds approximately to two-digit SIC industries), in several dozen countries, annually over the period 1963 to 1995 . Value added is defined as the value of shipments of goods produced (output) minus the cost of intermediate goods and required services (but not including labor), with appropriate adjustments made for inventories of finished goods, work-in-progress, and raw materials. In other words, this value added measure reflects value added by labor as well as capital. Gross fixed capital formation is defined as the cost of new and used fixed assets minus the value of sales of used fixed assets, where fixed assets include land, buildings, and machinery and equipment (United Nations Statistical Office, 1983). Note that mergers within an industry would not be counted as capital formation, but mergers across industries would be counted as increased capital in the acquirer's industry and reduced capital in the acquired firm's industry. This is desirable for our purpose.

To the CD-ROM data I added approximately 50 country-years of data that are available in recent hard-copy G.I.S. volumes. Even after these additions, most countries do not have complete data for all 28 industries and all 33 years. A few countries do not report data for a very wide range of manufacturing industries. For instance, Barbados, Libya, and Swaziland usually report on fewer than ten industries per year. Cameroon and Malawi also report on fewer than ten industries in a significant number of years. This likely reflects a combination of unsuitably aggregated statistics as collected by the country as well as their real lack of industrial diversification.

Table 1 reports summary statistics for total manufacturing investment, industry $\log$ investment growth, and industry log value added growth. ${ }^{1}$ (Logs reduce skewness.) I study the 65 nonsocialist countries that have at least 50 useful industry-year observations and for which I can find some financial development data (described below). To reduce the influence of outliers, I exclude observations for which the absolute value of either log investment growth or log value added growth exceeds one (that is, an increase of more than $172 \%$ or a decrease of more than $63 \%$ ). Also, to focus on economically important industries,

\footnotetext{
${ }^{1}$ Raw data on capital formation and value added are adjusted to current U.S. dollars using the year-average exchange rate reported by the IMF's International Financial Statistics. To convert into real dollars, capital formation is deflated by the U.S. capital goods producer price index and value added is deflated by the U.S. finished goods PPI (base year 1982 for both). This procedure implicitly assumes purchasing power parity for capital goods and finished goods. I also use price indexes for capital goods and finished goods from the Penn World Table 5.6 (Summers and Heston, 1991) to adjust for deviations from PPP. This does not alter any main results, but reduces sample sizes because price indexes are not available for all countries and years for which I have industry-level data. My reported results are therefore based on the simpler adjustment.
} 
Table 1

Summary statistics of total manufacturing investment, industry investment growth, and industry value added growth

Summary statistics for the total manufacturing investment-output ratio, log industry investment growth, and log industry value added growth for 65 non-socialist countries. ISIC-3 industry-year data on gross fixed capital formation, output, and value added are from the 1997 United Nations' INDSTAT-3 database. Countries report nominal data for up to 28 ISIC-3 manufacturing industries per year. The third column indicates the first and last years for which useful data are available, but for some countries there are interruptions within this range. Values are converted to current U.S. dollars using the year-average exchange rate reported by the IMF's International Financial Statistics. Real gross capital formation in industry $i$ in country $c$ in year $t\left(I_{i c t}\right)$ is then computed by deflating the nominal series by the U.S. capital goods producer price index (base year 1982). Real value added $\left(V_{i c t}\right)$ and real output are computed by deflating the nominal series by the U.S. finished goods producer price index (base year 1982). The mean manufacturing investment-output ratio is the ratio of total manufacturing investment to total manufacturing output, averaged across years. Observations with absolute values exceeding one for either log investment growth or log value added growth, and those that constitute less than $0.1 \%$ of the country's total manufacturing value added in that year, are excluded.

\begin{tabular}{|c|c|c|c|c|c|c|c|}
\hline \multirow[b]{2}{*}{ Country } & \multirow[b]{2}{*}{$N$} & \multirow{2}{*}{$\begin{array}{l}\text { Data } \\
\text { range }\end{array}$} & \multirow{2}{*}{$\begin{array}{l}\text { Mean mfg. } \\
\text { investment- } \\
\text { output ratio }\end{array}$} & \multicolumn{2}{|c|}{$\ln I_{i c t} / I_{i c t-1}$} & \multicolumn{2}{|c|}{$\ln V_{i c t} / V_{i c t-1}$} \\
\hline & & & & Mean & SD & Mean & SD \\
\hline Australia & 526 & $1963-85$ & 0.043 & -0.009 & 0.327 & 0.015 & 0.123 \\
\hline Austria & 686 & 1969-94 & 0.059 & 0.041 & 0.316 & 0.042 & 0.162 \\
\hline Bangladesh & 180 & $1981-92$ & 0.033 & 0.051 & 0.479 & 0.066 & 0.302 \\
\hline Barbados & 149 & 1970-94 & 0.040 & -0.002 & 0.506 & 0.030 & 0.325 \\
\hline Belgium & 510 & $1963-95$ & 0.053 & 0.029 & 0.330 & 0.043 & 0.152 \\
\hline Bolivia & 193 & $1970-94$ & 0.069 & 0.109 & 0.487 & 0.083 & 0.273 \\
\hline Cameroon & 87 & $1976-94$ & 0.074 & 0.046 & 0.516 & 0.018 & 0.380 \\
\hline Canada & 670 & $1963-90$ & 0.044 & 0.034 & 0.311 & 0.031 & 0.111 \\
\hline Chile & 500 & 1964-94 & 0.059 & 0.020 & 0.481 & 0.022 & 0.238 \\
\hline Colombia & 598 & 1963-94 & 0.037 & 0.029 & 0.461 & 0.050 & 0.183 \\
\hline Cyprus & 472 & $1971-95$ & 0.056 & 0.006 & 0.444 & 0.067 & 0.203 \\
\hline Denmark & 604 & $1963-91$ & 0.044 & 0.044 & 0.359 & 0.040 & 0.152 \\
\hline Ecuador & 579 & 1963-94 & 0.098 & 0.066 & 0.463 & 0.047 & 0.269 \\
\hline Egypt & 434 & 1967-93 & 0.147 & -0.038 & 0.520 & 0.032 & 0.356 \\
\hline El Salvador & 117 & $1978-85$ & 0.036 & -0.049 & 0.516 & -0.037 & 0.325 \\
\hline Ethiopia & 179 & $1965-89$ & 0.134 & -0.031 & 0.530 & 0.053 & 0.183 \\
\hline Fiji & 197 & 1970-92 & 0.050 & -0.021 & 0.514 & 0.039 & 0.282 \\
\hline Finland & 723 & 1963-94 & 0.062 & 0.021 & 0.401 & 0.039 & 0.176 \\
\hline France & 325 & $1963-95$ & 0.064 & 0.027 & 0.223 & 0.052 & 0.134 \\
\hline Germany & 631 & $1964-92$ & 0.048 & 0.040 & 0.216 & 0.040 & 0.132 \\
\hline Greece & 629 & $1963-92$ & 0.066 & 0.012 & 0.416 & 0.055 & 0.166 \\
\hline Guatemala & 198 & $1974-88$ & 0.027 & -0.024 & 0.499 & -0.006 & 0.330 \\
\hline Hong Kong & 318 & $1975-93$ & 0.036 & 0.045 & 0.421 & 0.042 & 0.181 \\
\hline India & 413 & $1977-93$ & 0.066 & 0.058 & 0.369 & 0.020 & 0.197 \\
\hline Indonesia & 434 & $1970-95$ & 0.085 & 0.036 & 0.454 & 0.140 & 0.296 \\
\hline
\end{tabular}


Table 1 (continued)

\begin{tabular}{|c|c|c|c|c|c|c|c|}
\hline \multirow[b]{2}{*}{ Country } & \multirow[b]{2}{*}{$N$} & \multirow{2}{*}{$\begin{array}{l}\text { Data } \\
\text { range }\end{array}$} & \multirow{2}{*}{$\begin{array}{l}\text { Mean mfg. } \\
\text { investment- } \\
\text { output ratio }\end{array}$} & \multicolumn{2}{|c|}{$\ln I_{\text {ict }} / I_{\text {ict }-1}$} & \multicolumn{2}{|c|}{$\ln V_{i c t} / V_{i c t-1}$} \\
\hline & & & & Mean & SD & Mean & SD \\
\hline Iran & 302 & 1963-93 & 0.073 & -0.012 & 0.480 & 0.013 & 0.367 \\
\hline Ireland & 550 & 1963-91 & 0.043 & 0.034 & 0.404 & 0.049 & 0.159 \\
\hline Israel & 431 & 1963-94 & 0.053 & 0.065 & 0.404 & 0.049 & 0.170 \\
\hline Italy & 522 & 1967-91 & 0.055 & 0.052 & 0.245 & 0.045 & 0.176 \\
\hline Japan & 814 & $1963-93$ & 0.047 & 0.054 & 0.276 & 0.080 & 0.140 \\
\hline Jordan & 263 & 1974-94 & 0.362 & 0.010 & 0.400 & 0.080 & 0.287 \\
\hline Kenya & 61 & $1967-71$ & 0.085 & 0.054 & 0.491 & 0.122 & 0.152 \\
\hline Korea (South) & 682 & 1966-94 & 0.092 & 0.116 & 0.425 & 0.148 & 0.188 \\
\hline Kuwait & 290 & 1968-94 & 0.080 & 0.024 & 0.508 & 0.062 & 0.349 \\
\hline Libya & 99 & $1964-80$ & 0.365 & 0.065 & 0.450 & 0.060 & 0.333 \\
\hline Macao & 145 & 1978-93 & 0.003 & -0.020 & 0.539 & 0.093 & 0.300 \\
\hline Malawi & 172 & 1964-94 & 0.069 & -0.025 & 0.527 & 0.012 & 0.365 \\
\hline Malaysia & 334 & 1968-94 & 0.064 & 0.159 & 0.402 & 0.150 & 0.192 \\
\hline Malta & 390 & $1963-93$ & 0.041 & -0.027 & 0.485 & 0.062 & 0.226 \\
\hline Mexico & 362 & $1970-91$ & 0.043 & 0.053 & 0.428 & 0.041 & 0.229 \\
\hline Morocco & 108 & 1985-94 & 0.060 & 0.094 & 0.405 & 0.078 & 0.163 \\
\hline Netherlands & 616 & $1963-93$ & 0.047 & 0.031 & 0.292 & 0.043 & 0.139 \\
\hline New Zealand & 377 & $1963-90$ & 0.043 & 0.013 & 0.388 & 0.038 & 0.153 \\
\hline Nigeria & 161 & $1963-90$ & 0.102 & 0.018 & 0.493 & 0.093 & 0.358 \\
\hline Norway & 717 & $1963-92$ & 0.053 & 0.035 & 0.379 & 0.025 & 0.156 \\
\hline Pakistan & 176 & 1965-91 & 0.087 & -0.032 & 0.438 & 0.078 & 0.283 \\
\hline Panama & 333 & 1963-91 & 0.054 & -0.018 & 0.504 & 0.041 & 0.215 \\
\hline Peru & 201 & 1982-92 & 0.031 & 0.009 & 0.492 & 0.032 & 0.366 \\
\hline Philippines & 527 & 1963-93 & 0.047 & 0.035 & 0.469 & 0.041 & 0.306 \\
\hline Portugal & 557 & $1971-94$ & 0.066 & 0.034 & 0.409 & 0.047 & 0.197 \\
\hline Singapore & 642 & 1963-94 & 0.053 & 0.074 & 0.424 & 0.099 & 0.194 \\
\hline Spain & 563 & 1964-92 & 0.039 & 0.041 & 0.329 & 0.046 & 0.159 \\
\hline Sri Lanka & 126 & 1979-93 & 0.049 & 0.050 & 0.551 & -0.021 & 0.341 \\
\hline Swaziland & 53 & 1970-90 & 0.127 & -0.013 & 0.517 & 0.012 & 0.329 \\
\hline Sweden & 565 & $1963-87$ & 0.062 & 0.010 & 0.297 & 0.031 & 0.139 \\
\hline Tanzania & 220 & 1965-91 & 0.086 & -0.049 & 0.479 & 0.042 & 0.314 \\
\hline Trinidad \& Tobago & 73 & 1967-91 & 0.044 & -0.023 & 0.531 & -0.004 & 0.282 \\
\hline Tunisia & 387 & $1963-95$ & 0.074 & 0.047 & 0.437 & 0.087 & 0.215 \\
\hline Turkey & 596 & 1963-94 & 0.052 & 0.038 & 0.434 & 0.062 & 0.259 \\
\hline United Kingdom & 620 & $1968-91$ & 0.040 & 0.018 & 0.263 & 0.027 & 0.142 \\
\hline United States & 868 & $1963-95$ & 0.034 & 0.027 & 0.186 & 0.022 & 0.091 \\
\hline Uruguay & 85 & 1989-93 & 0.027 & -0.009 & 0.468 & 0.038 & 0.227 \\
\hline Venezuela & 352 & 1976-93 & 0.065 & -0.051 & 0.457 & -0.029 & 0.273 \\
\hline Zambia & 106 & $1963-75$ & 0.070 & -0.009 & 0.498 & 0.132 & 0.257 \\
\hline Zimbabwe & 403 & $1963-94$ & 0.052 & 0.019 & 0.456 & 0.027 & 0.197 \\
\hline Full Sample & 25,201 & $1963-95$ & $\begin{array}{c}0.069 \\
\text { (equal-wtd.) }\end{array}$ & $\begin{array}{r}0.030 \\
(N \text {-wtd. })\end{array}$ & $\begin{array}{c}0.402 \\
(N \text {-wtd.) }\end{array}$ & $\begin{array}{r}0.050 \\
(N \text {-wtd. })\end{array}$ & $\begin{array}{c}0.217 \\
(N \text {-wtd. })\end{array}$ \\
\hline
\end{tabular}


I exclude those for which value added is less than $0.1 \%$ of the country's total manufacturing value added in that year. Including these small industries does not alter any results. Together, these criteria eliminate about $12 \%$ of the otherwise available observations.

Table 1 summarizes the basic manufacturing statistics data for each country. Across countries, the average ratio of manufacturing investment to output is $6.9 \%$ and is usually under $10 \%$ except in certain oil-producing countries that invested very heavily around the time of the oil shocks. In addition, industry investment growth averages $3.0 \%$ and value added growth averages $5.0 \%$ (weighted by the number of observations). The industry growth series are naturally much more volatile than their aggregate counterparts. Industries in the U.S. have been the most stable over this period, both in terms of investment growth and value added growth.

\subsection{Measuring the efficiency of capital allocation}

The available capital formation series is not long enough to sum up to obtain industry capital stock measures. This makes it difficult to estimate a structural investment equation based on production theory. Faced with this data constraint, I adopt a simple and transparent methodology. I assume that optimal investment implies increasing investment in industries that are "growing" and decreasing investment in industries that are "declining." Since the sum of value added across all firms in the economy is GDP, and economic growth is typically measured as growth in GDP, growth in industry value added is the most natural way to measure industry growth. I use growth in industry gross fixed capital formation to measure growth in investment, since depreciation is also not available.

I estimate the following simple specification for each country:

$$
\ln \frac{I_{i c t}}{I_{i c t-1}}=\alpha_{c}+\eta_{c} \ln \frac{V_{i c t}}{V_{i c t-1}}+\varepsilon_{i c t}
$$

where $I$ is gross fixed capital formation, $V$ is value added, $i$ indexes manufacturing industry, $c$ indexes country, and $t$ indexes year. The slope estimate in Eq. (1) is an elasticity. It measures the extent to which country $c$ increases investment in its growing industries and decreases investment in its declining industries.

There are several remarks to make about this specification. First, is there a traditional way to think about the slope coefficient? Hubbard (1998) discusses a widely used model of firm investment in which "capital adjustment costs" are quadratic, and the response of investment to Q depends inversely on a multiplicative adjustment cost parameter. The intuition in that model is that investment is more responsive to investment opportunities when adjustment costs are low. By analogy, the country-specific slope coefficients estimated from Eq. (1) reflect a general notion of capital adjustment costs. The fact that the slope coefficients 
turn out to be very strongly related to financial development suggests capital market frictions, as opposed to purely technological adjustment costs such as the time and effort required to install a piece of equipment.

Second, given the premise that value added growth reflects investment opportunities, it is important to verify that value added growth is correlated with more traditional measures of investment opportunities. The WorldScope database contains enough data on U.S. firms to make a meaningful comparison, at least for the U.S. series. I use primary SIC codes to group U.S. firms in WorldScope by ISIC industry, using the U.S. Department of Commerce (1979) SIC to ISIC correspondence. I compute average values of average Q, the $\log$ price-earnings ratio, and $\log$ sales growth across all U.S. firms within that ISIC industry-year. ${ }^{2}$ The correlations between industry value added growth and $\mathrm{Q}$, the priceearnings ratio, and sales growth are $0.344,0.513$, and 0.614 , respectively. All three of these correlations are highly significant. They suggest that value added growth is a reasonable, if imperfect, measure of investment opportunities. ${ }^{3}$

Third, reverse causality might appear to be a concern in Eq. (1). Perhaps investment causes a contemporaneous change in value added. Prior literature has found, however, that fixed capital does not become productive until an average of two years after the investment decision has been made; Mayer (1960) and Hall (1977) provide U.S. evidence on gestation lags. For investment to influence value added contemporaneously, fixed capital expenditures would have to become productive immediately.

Fourth, international differences in data quality and reporting standards can affect the comparability of the data. ${ }^{4}$ Two aspects of my methodology tend to

\footnotetext{
${ }^{2}$ To ensure that the industry-level aggregate is an accurate reflection of broad industry conditions, I include only industries in which at least 20 firms are covered in WorldScope. In addition, WorldScope reports at most ten years of data on any one firm, and does not include inactive firms, so most of the observations are from 1986 or later.
}

${ }^{3}$ These correlations would surely be higher if the matching across data sets was more exact. In practice, constructing industry-level aggregates from WorldScope requires one to group many highly diversified firms along with single line of business firms according to primary SIC, to force firm fiscal years into calendar years even if the overlap is barely more than six months, and to make arbitrary classifications where the SIC to ISIC correspondence is not one-to-one.

\footnotetext{
${ }^{4}$ Fitzgerald et al. (1979) summarize international difference in accounting practices. (Their survey is now dated but appropriate for my sample period.) One difference is the tendency to record and disclose segment-specific data. It is not clear whether the data transmitted to the United Nations Statistical Office utilizes all available segment data, but it is certainly unlikely that such data will be transmitted if it is not recorded in the firm's own financial statements. Fitzgerald et al. report that "sales for each class of diverse activities" is minority practice or rare in nearly all countries, as of 1979, with the exception of Canada, India, Pakistan, the United Kingdom, and the United States. Another prominent difference is the practice of valuing assets at historical or current cost. This is less significant for our purposes since we are considering (growth in) the investment (flow) variable, which is essentially always current cost. (Excluding the few high-inflation countries in the sample does not alter any cross-country results.)
} 
counteract the potential influence of differences in accounting practices. First, using value added and investment aggregated to industry levels smoothes cross-firm differences in reporting procedures. Second, using growth rates allows cross-country comparability even if some countries adopt different accounting definitions of the underlying economic quantity, so long as those definitions are consistent over time. Nevertheless, potentially heterogeneous data quality goes with the territory of cross-country analysis, and this study is no exception. One reassuring calculation in Section 3 indicates that the cross-country differences in the elasticity estimates from Eq. (1) are simply too large to be attributed to international differences in measurement error and the resulting attenuation biases.

Fifth, firms in some countries can be differentially financially constrained, which could show up as a higher sensitivity of investment to current cash flow by the logic of Fazzari et al. (1988). This could be a problem if value added growth measures internal cash flow more than investment opportunities. However, the pattern of elasticity estimates across countries is inconsistent with this interpretation. One would need to explain why firms in Germany and the U.S. (which have comparatively high elasticity estimates) are more financially constrained than firms in India and Indonesia, for example. Only the reverse pattern is plausible.

Sixth, one might suggest modifications to the form of Eq. (1). I arrived at this simple specification after estimating more elaborate ones which give similar results. For instance, industry effects are not usually jointly significant, so including 28 of them is not worth the degrees of freedom lost in countries with few observations. Nor does including lags of value added growth change the basic results. Coefficients on contemporaneous value added growth tend to be three times higher than coefficients on one-year-lagged value added growth. Another benefit is expositional: excluding these lags allows us to focus on a single coefficient for cross-country comparisons.

Seventh, the specification does not include year effects. The slope coefficient in Eq. (1) credits the country both for investing in the right industries at a given point in time and for marshaling higher overall investment when overall growth is high. These two dimensions are analogous to the two problems facing a fund manager: portfolio selection (with a given amount of investment at a point in time) and market timing (varying the total invested across time). Obviously, both dimensions are required for a complete understanding of capital allocation. In Section 3, I decompose these basic elasticity estimates into within-year and between-year components. I also discuss the results of allowing asymmetry in the elasticity, which addresses whether a high sensitivity of investment growth to value added growth reflects increased investment in growing industries, decreased investment in declining industries, or both. These exercises are important for determining the robustness of the results and also for understanding their sources. 
My approach to measuring the efficiency of investment is quite different than that taken by a small prior literature. A few papers study capital allocation in a single developing country, with an eye toward assessing changes over time. Gupta and Lensink (1996) summarize studies by Cho (1988) for Korea and Capoglu (1980) for Turkey. Their methodology is to estimate the variance of the expected marginal returns to capital (in some cases, marginal costs of capital) across industries and compare this variance before and after a financial deregulation event. If the variance falls, they infer that the liberalization encouraged flows of capital to equate marginal returns across industries.

While this methodology has the appeal of being grounded in production theory, its power in practice depends on accurately measuring the expected marginal return to capital. Financial economists are acutely aware that how to do this for a single firm, let alone for an entire industry, set of industries, or set of countries, is not uncontroversial. Another difficulty is the lack of data on industry capital stocks. A third is the required inference that any reduction in the dispersion of returns is actually due to improved capital allocation. Shifts in industrial organization, product or factor market shocks, or other types of economic liberalizations are likely to occur near financial liberalizations (Henry, 2000), but they must be ruled out. Finally, note that my methodology allows me to judge allocative efficiency from direct observation of investment flows. I believe this is more transparent and far more convincing than inferring it from the distribution of estimated shadow prices or shadow values of capital.

\subsection{Financial system data}

The ideal measure of financial development would be the all-in cost of capital for a given investment project. Unfortunately, there are no reliable international data on the cost of external capital. Lacking data on the price of finance, researchers use quantity as a summary indicator of financial development. The presumption is that more financing activity reflects a lower cost of capital and, implicitly, a more competitive financial market with better institutions. I thus follow Goldsmith (1969), King and Levine (1993), La Porta et al. (1997), and Rajan and Zingales (1998) in taking the size of a country's equity and credit markets relative to its GDP as a proxy for the general level of financial development. (La Porta et al. measure the amount of purely external finance in stock markets by adjusting for ownership by insiders. Their measure and the broader measure that I use are highly correlated.)

The aggregate market capitalization of international public equity markets is tabulated in the International Finance Corporation's Emerging Stock Markets Factbook. Private domestic credit and nonfinancial public credit are tabulated in the International Financial Statistics Yearbook. I obtain nominal GDP from the Penn World Tables, version 5.6 (Summers and Heston, 1991). I compute 1980, 1985 , and 1990 values for the ratios of market capitalization to GDP and credit 
to GDP, then average these values to smooth out cyclical variations. (Equity market data are not available for a wide range of countries before 1980.) $S T K / G D P$ (stock market capitalization to GDP) and $C R E D / G D P$ (credit to GDP) are logs of one plus these average values. A summary measure of financial development, $F D$, is the $\log$ of one plus the average sum of stock market capitalization and credit to GDP.

These variables are summarized in the Appendix. FD is lowest in Zambia, which had no stock market during this period, and highest in Japan, which had an extensive credit market. In the typical country in the sample, the credit market is two to three times the size of the stock market. These figures and the international ranges are similar to those reported by prior authors for smaller sets of countries. The Appendix also reports the 1960 value of per capita GDP; the date is chosen to minimize the potential for endogeneity when this variable is used as a control in cross-country regressions.

After comparing these basic levels of financial development to the estimates of the efficiency of capital allocation, I look at more specific potential determinants suggested by various theories. I use stock price "synchronicity" data from Morck et al. (2000). They measure the synchronicity of stock prices (i.e., the extent to which stock returns on individual firms move together) in a few dozen stock markets in 1995. I use the data they report on the fraction of stocks that move in the same direction in a given week in the first half of 1995 (their sample period) as a country-specific measure of stock synchronicity, SYNCH. Among countries with these data, the U.S. stock market exhibits the least synchronicity, with $57.9 \%$ of firms' stock prices moving in the same direction in a given week, while Turkey at $74.4 \%$ and Malaysia at $75.4 \%$ exhibit the most synchronicity.

I also use data on the prevalence of state-owned enterprise from the World Bank (1995). Specifically, I use the share of total nonagricultural GDP due to state-owned enterprise. The earliest available data are from 1978. I take the 1978-1985 average for each country and call the resulting variable SOE. For countries with no data before 1985, I take the 1986-1991 average. Among countries with these data, the United Kingdom has the lowest proportion of state-owned activity, at $1.3 \%$, and Egypt has the highest, at $51.1 \%$.

Finally, I use data on the legal rights of external investors from La Porta et al. (1998). They tabulate how many out of six shareholder protections (e.g., proxy voting by mail) are written into the commercial code of each country, and how many out of four creditor protections (e.g., secured creditors are first in line for distribution of bankruptcy proceeds) are written into its bankruptcy and reorganization laws. To form a summary measure of the "effective" legal rights, RIGHTS, I multiply the number of these investor rights that exist in the law (0 to 10 , integer) by La Porta et al.'s measure of the domestic "rule of law" (0 to 1 , continuous). This reflects an intuition that strong but unenforced laws are not useful, nor is a policy of strict enforcement of fundamentally weak laws. Among countries covered by La Porta et al., Mexico scores lowest at 0.54 out of 10 . 
Colombia and Peru are next lowest. The United Kingdom scores highest at 7.71, followed closely by Hong Kong and New Zealand.

\section{Estimates and determinants of the efficiency of capital allocation}

In this section I first report country-specific estimates of the investment-value added elasticity based on Eq. (1). I then show that financial market variables explain some of the cross-country variation in this measure of the efficiency of capital allocation.

\subsection{The efficiency of capital allocation in 65 countries}

Table 2 reports the country elasticity estimates from Eq. (1). One notable and reassuring feature is that all but two of them are estimated to be positive, and even the two exceptions (Bolivia and Swaziland) are not significantly negative. A second feature is that the range of estimates, and the fraction of withincountry variation in investment growth explained by value added growth, is very wide. The average country elasticity is 0.429 and the cross-country standard deviation is 0.288 . The highest elasticity estimate is Germany's at 0.988. The next highest estimates are for Hong Kong, New Zealand, France, Spain, Denmark, and Sweden. Japan is 9th highest, the United Kingdom is 10th, and the U.S. is 13th. It strikes me as remarkable that the four moststudied financial systems, despite considerable institutional differences, all fall in the top quintile of the sample in terms of estimated efficiency of capital allocation.

The relationship fits best in Germany, with an $R^{2}$ of 0.364 . In general the countries with high elasticity estimates also have better fits. By contrast, in several developing countries the elasticity estimate is not significantly positive, and $R^{2}$ is close to zero. In these countries, investment is not ramped up in growing industries and is not slowed down in declining industries; factors unrelated to current growth prospects must play a large role.

Since these are elasticities, cross-country differences in the magnitudes are easy to interpret. For instance, consider a shock that causes value added growth of $10 \%$. Such a shock would not be unusual in any country, per Table 1 . The estimates in Table 2 imply that investment will increase by more than $7 \%$, on average, if the industry is in the U.S., but by only $1 \%$ if the industry is in India. This difference appears believable and economically important.

As discussed earlier, one potential criticism of these results is the possibility that data quality varies across countries due to differences in accounting standards, causing attenuation biases. However, the differences in data quality required to account for the range of estimates in Table 2 would have to be very large. For example, suppose the true country elasticity is 0.800 (e.g., as estimated 
Table 2

Estimates of the elasticity of industry investment to value added

Estimates of the elasticity of industry investment to industry value added in 65 nonsocialist countries. The estimates are obtained from the following regression, estimated for each country $c$ :

$$
\ln \frac{I_{i c t}}{I_{i c t-1}}=\alpha_{c}+\eta_{c} \ln \frac{V_{i c t}}{V_{i c t-1}}+\varepsilon_{i c t},
$$

where $i$ indexes ISIC-3 manufacturing industries, $c$ indexes countries, and $t$ indexes years. The number of observations in each country is reported in Table 1. Robust standard errors are in parentheses.

\begin{tabular}{|c|c|c|c|}
\hline Country & $\hat{\eta}_{c}(s e)$ & $R^{2}$ & Rank of $\hat{\eta}_{c}$ \\
\hline Australia & $0.681(0.134)$ & 0.065 & 14 \\
\hline Austria & $0.835(0.085)$ & 0.182 & 8 \\
\hline Bangladesh & $0.131(0.120)$ & 0.007 & 54 \\
\hline Barbados & $0.072(0.123)$ & 0.002 & 60 \\
\hline Belgium & $0.803(0.098)$ & 0.137 & 11 \\
\hline Bolivia & $-0.202(0.128)$ & 0.013 & 65 \\
\hline Cameroon & $0.134(0.149)$ & 0.010 & 53 \\
\hline Canada & $0.547(0.115)$ & 0.038 & 26 \\
\hline Chile & $0.294(0.100)$ & 0.021 & 40 \\
\hline Colombia & $0.130(0.108)$ & 0.006 & 55 \\
\hline Cyprus & $0.421(0.117)$ & 0.037 & 30 \\
\hline Denmark & $0.853(0.123)$ & 0.131 & 6 \\
\hline Ecuador & $0.305(0.071)$ & 0.031 & 39 \\
\hline Egypt & $0.326(0.069)$ & 0.050 & 36 \\
\hline El Salvador & $0.262(0.165)$ & 0.027 & 46 \\
\hline Ethiopia & $0.135(0.247)$ & 0.002 & 52 \\
\hline Fiji & $0.154(0.133)$ & 0.007 & 51 \\
\hline Finland & $0.557(0.087)$ & 0.059 & 25 \\
\hline France & $0.893(0.075)$ & 0.289 & 4 \\
\hline Germany & $0.988(0.061)$ & 0.364 & 1 \\
\hline Greece & $0.635(0.104)$ & 0.064 & 20 \\
\hline Guatemala & $0.633(0.091)$ & 0.176 & 21 \\
\hline Hong Kong & $0.948(0.132)$ & 0.166 & 2 \\
\hline India & $0.100(0.097)$ & 0.003 & 57 \\
\hline Indonesia & $0.217(0.077)$ & 0.020 & 50 \\
\hline Iran & $0.446(0.067)$ & 0.116 & 29 \\
\hline Ireland & $0.666(0.114)$ & 0.069 & 15 \\
\hline Israel & $0.263(0.107)$ & 0.012 & 45 \\
\hline Italy & $0.652(0.063)$ & 0.220 & 16 \\
\hline Japan & $0.819(0.074)$ & 0.174 & 9 \\
\hline Jordan & $0.322(0.096)$ & 0.053 & 37 \\
\hline Kenya & $0.068(0.389)$ & 0.000 & 61 \\
\hline Korea (South) & $0.646(0.089)$ & 0.082 & 18 \\
\hline
\end{tabular}


Table 2 (continued)

\begin{tabular}{|c|c|c|c|}
\hline Country & $\hat{\eta}_{c}(s e)$ & $R^{2}$ & Rank of $\hat{\eta}_{c}$ \\
\hline Kuwait & $0.047(0.087)$ & 0.001 & 63 \\
\hline Libya & $0.387(0.122)$ & 0.082 & 31 \\
\hline Macao & $0.237(0.147)$ & 0.017 & 32 \\
\hline Malawi & $0.075(0.115)$ & 0.003 & 59 \\
\hline Malaysia & $0.285(0.118)$ & 0.019 & 42 \\
\hline Malta & $0.268(0.102)$ & 0.016 & 44 \\
\hline Mexico & $0.344(0.114)$ & 0.034 & 34 \\
\hline Morocco & $0.638(0.227)$ & 0.066 & 19 \\
\hline Netherlands & $0.573(0.093)$ & 0.074 & 24 \\
\hline New Zealand & $0.896(0.130)$ & 0.125 & 3 \\
\hline Nigeria & $0.364(0.106)$ & 0.070 & 33 \\
\hline Norway & $0.575(0.093)$ & 0.056 & 23 \\
\hline Pakistan & $0.255(0.130)$ & 0.027 & 47 \\
\hline Panama & $0.064(0.125)$ & 0.001 & 62 \\
\hline Peru & $0.651(0.081)$ & 0.234 & 17 \\
\hline Philippines & $0.313(0.075)$ & 0.042 & 38 \\
\hline Portugal & $0.539(0.097)$ & 0.068 & 27 \\
\hline Singapore & $0.486(0.088)$ & 0.049 & 28 \\
\hline Spain & $0.867(0.077)$ & 0.175 & 5 \\
\hline Sri Lanka & $0.273(0.156)$ & 0.029 & 43 \\
\hline Swaziland & $-0.069(0.217)$ & 0.002 & 64 \\
\hline Sweden & $0.852(0.083)$ & 0.159 & 7 \\
\hline Tanzania & $0.087(0.102)$ & 0.003 & 58 \\
\hline Trindad \& Tobago & $0.340(0.250)$ & 0.032 & 35 \\
\hline Tunisia & $0.287(0.116)$ & 0.020 & 41 \\
\hline Turkey & $0.242(0.072)$ & 0.021 & 48 \\
\hline United Kingdom & $0.812(0.092)$ & 0.192 & 10 \\
\hline United States & $0.723(0.069)$ & 0.126 & 13 \\
\hline Uruguay & $0.218(0.257)$ & 0.011 & 49 \\
\hline Venezuela & $0.593(0.082)$ & 0.125 & 22 \\
\hline Zambia & $0.123(0.182)$ & 0.004 & 56 \\
\hline Zimbabwe & $0.726(0.116)$ & 0.099 & 12 \\
\hline Mean & 0.429 & 0.071 & (Out of 65) \\
\hline Median & 0.344 & 0.042 & \\
\hline SD & 0.288 & 0.078 & \\
\hline
\end{tabular}

for Belgium) but the least-squares estimate is 0.200 (e.g., as estimated for Indonesia). If white noise measurement error is to account for this difference, the variance of the measurement error (the noise) in industry value added growth must be a full three times the true variance of industry value added growth (the 
signal). ${ }^{5}$ Thus, while accounting standards undoubtedly differ greatly across countries, it seems unlikely that spherical measurement error is the driving force behind the sizeable differences in the estimated efficiency of capital allocation.

\subsection{Capital market size and the quality of capital allocation}

What explains these international differences in the elasticity of industry investment to value added? As a first step, Fig. 1 plots the estimates from Table 2 on the summary measure of financial development. Hong Kong and Macao are not plotted due to missing data on the size of their credit markets, but based on the size of their stock markets alone, we would expect Hong Kong to plot near the upper-right extreme and Macao to plot at the lower-left extreme. Although there are a few countries that do not fit the pattern, the figure reveals a strong positive association between the country elasticity estimates and the general level of financial development. The correlation between the country elasticities and the size of financial markets is 0.554 . This is the central result of the paper.

Table 3 explores this relation in more detail. I regress the country elasticity estimates on alternative measures of financial development. Specification (1) shows that the summary financial development measure is strongly positively associated with the country elasticity $(t$-statistic $=5.28)$, as suggested in the figure. Specifications (2) and (3) show that the size of both stock markets and credit markets are individually also associated with high investment-value added elasticities. When both stock market size and credit market size are included in the same specification, as in (4), credit market size dominates. Specification (5) shows that per capita GDP is also strongly positively associated with the country elasticities, partly reflecting the correlation of financial development and income but also suggesting nonfinancial determinants of the allocation of capital. However, a strong independent effect of financial development remains even after controlling for GDP, as indicated by specification (6).

It is possible that financial markets, particularly stock markets, capitalize the expectation that a firm's future investment opportunities will or will not go unfunded and that valuations are therefore higher in certain countries precisely because they are better at allocating capital. In an attempt to isolate the exogenous influence of financial development, specifications (8) and (9) use country of legal origin (English, French, German, or Scandinavian) as an

${ }^{5}$ This follows from the formula for asymptotic bias due to a badly measured independent variable:

$$
\operatorname{plim} \hat{\gamma}=\gamma /\left(1+\frac{\sigma_{u}^{2}}{\sigma_{x^{*}}^{2}}\right),
$$

where $\hat{\gamma}$ is the least-squares estimate, $\gamma$ is the true parameter, $x=x^{*}+u$ is the observed badly measured variable, and $u$ is white noise measurement error. 


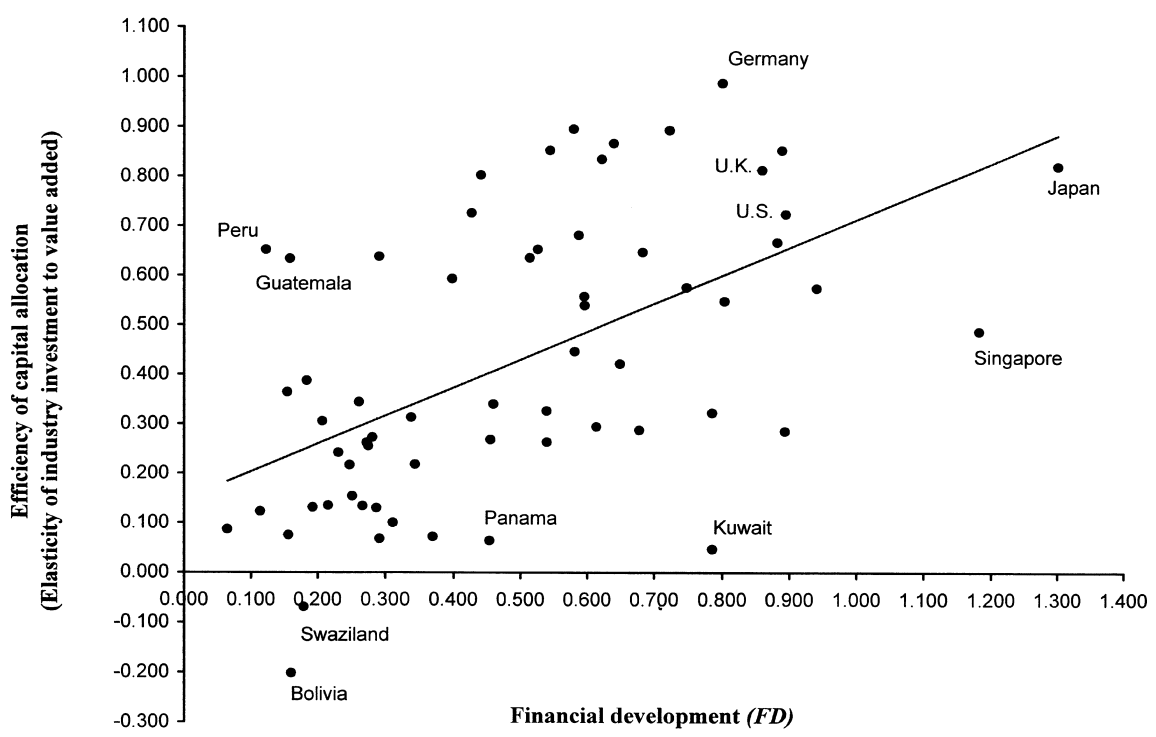

Fig. 1. The efficiency of capital allocation versus financial development. The figure plots countryspecific estimates of the elasticity of industry investment to value added for or 63 nonsocialist countries with data on the size of both stock and debt markets. Elasticity estimates are produced from regressions of the form

$$
\ln \frac{I_{i c t}}{I_{i c t-1}}=\alpha_{c}+\eta_{c} \ln \frac{V_{i c t}}{V_{i c t-1}}+\varepsilon_{i c t}
$$

as reported in Table 2. Financial development is measured as the natural log of one plus the sum of stock market capitalization to GDP and private and nonfinancial public domestic credit to GDP (where the sum is averaged over 1980, 1985, and 1990 values) as reported in the Appendix.

instrument for FD. La Porta et al. (1997) argue that the legal protections provided to outside investors are an important determinant of financial development. They also observe that these legal protections are determined to a large extent by the colonial history of the country. Country of legal origin therefore makes a plausible instrument for financial development. Levine (1997) also uses this instrument to study the effects of financial development on economic growth.

Specification (8) shows that the component of $F D$ predetermined by legal origin actually has a larger impact on the investment-value added elasticity than suggested in the analogous ordinary least-squares specification. This does not support the endogeneity hypothesis offered above. Instead, the independent effect of financial development over per capita GDP suggests that the basic relation reflects, at least in part, the influence of purely financial characteristics.

Finally, it is important to note that the financial market variables explain a significant portion of the variation in capital allocation quality across 


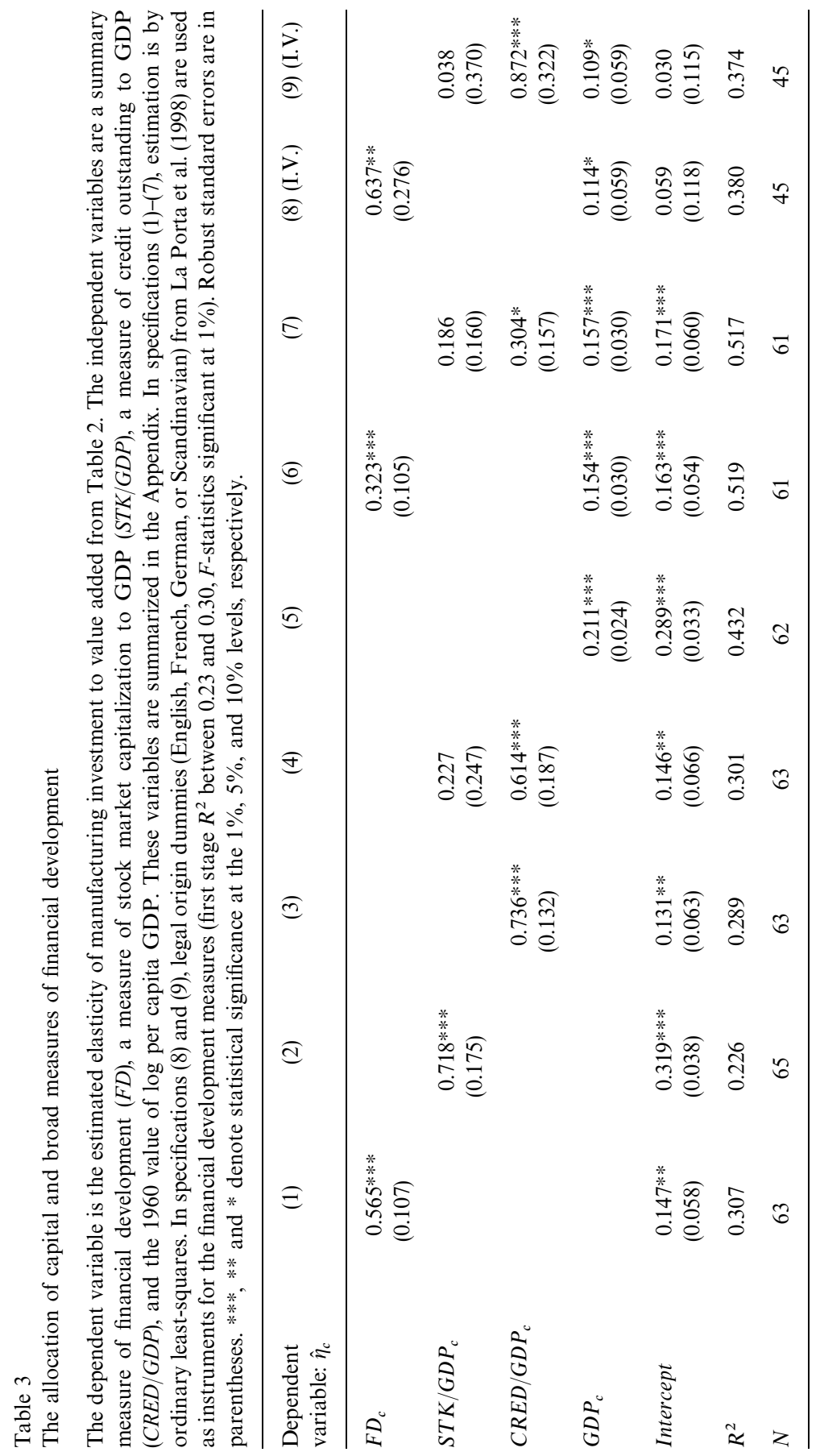


countries. While there remains much unexplained variation, as is clear from Fig. 1, the results strongly suggest that financial market characteristics are first-order determinants of the quality of capital allocation.

In unreported regressions, I find no significant positive relationship between the average manufacturing investment level (as measured by the investment-output ratio reported in Table 1) and financial development. A similar result is reported by Carlin and Mayer (1998) and Beck et al. (2000).

Given that the total level of manufacturing investment does not vary much according to the degree of financial development, the results in Table 3 imply that financially undeveloped countries either "underinvest" in growing industries or "overinvest" in declining industries or both. Which is it? Table 4 explores these issues. The dependent variable in specifications (1)-(3) is the country-specific investment to value added elasticity estimated using just the observations in which industry value added was growing $(15,898$ out of 25,201 industry-year observations or $63 \%$ ). Specifications (4)-(6) analyze the elasticity using just the observations in which the industry was in decline $(37 \%)$.

The results indicate that financial development is associated both with increasing investment in growing industries and with decreasing investment in declining industries. Interestingly, specification (6) shows that the level of income is not a significant determinant of the extent to which declining industries restrain investment, but financial development is. This hints at a governance role for external finance, a hypothesis supported by evidence presented later on the importance of investor rights.

Specifications (7)-(12) analyze the between-year and within-year components of the elasticity estimates. The between-year elasticity addresses whether manufacturing-sector-wide investment growth responds to manufacturing-sectorwide value added growth. It is estimated by regressing the average investment growth across industries in a given year on the average value-added growth across industries in that year. Thus, there are at most 33 observations in a given country for this regression (one per year). The within-year elasticity is the year fixed-effects estimator, i.e., Eq. (1) including year dummies. It addresses whether investment growth across industries is related to value added growth within a given year.

The results indicate that financial development is significantly positively related to both within-year and between-year aspects of capital allocation. Also, both of these sources of variation in value added growth are important to the overall variation; the mean within-year estimate is 0.239 , the mean between-year estimate is 0.766 , and the mean overall estimate (from Table 2) is 0.429 . The overall estimate is a weighted average of the within-year and between-year estimates, with the weight depending on which dimension of variation dominates the overall variation. For the average country, a proportion of 0.543 of the 


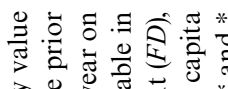

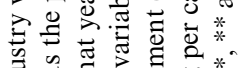

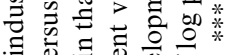

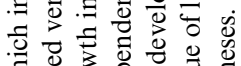

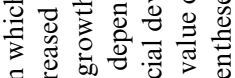

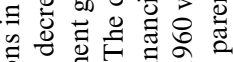

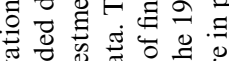

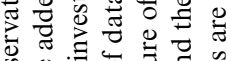

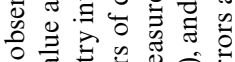

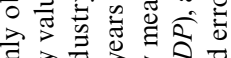
흘 on

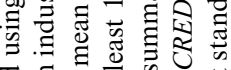
क्ष

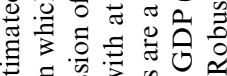

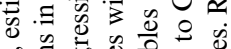
任

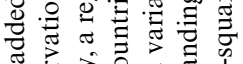

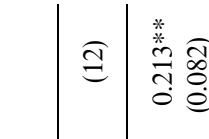

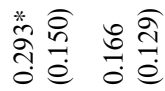

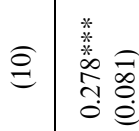

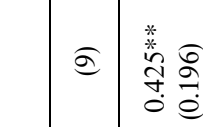

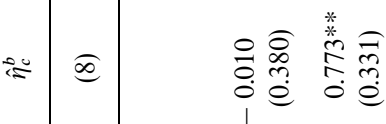

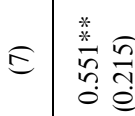

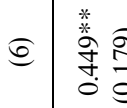

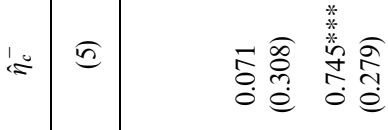

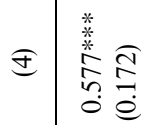

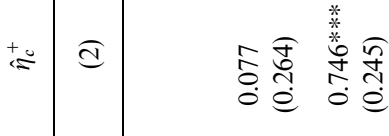$$
\Xi \mid \begin{array}{ll}
* \\
\stackrel{*}{*} \\
\stackrel{*}{*} & \frac{2}{0} \\
0 & 0
\end{array}
$$

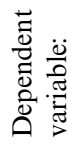

$$
\begin{aligned}
& \text { 華令 }
\end{aligned}
$$

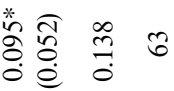

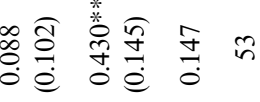

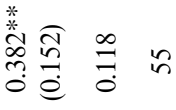

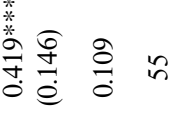

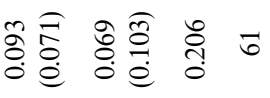

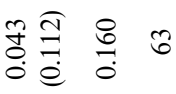

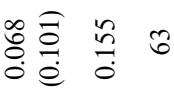

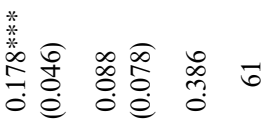

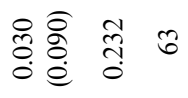

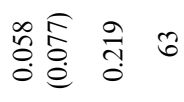

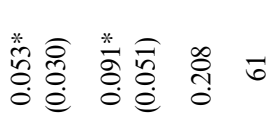

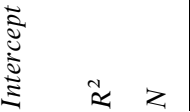

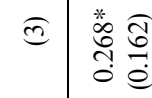$$
\text { ปิ่ }
$$

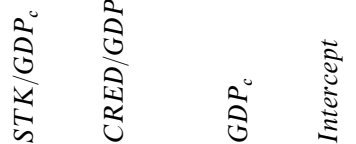


overall estimate is due to the between-year estimate with the remainder coming from the within-year estimate. ${ }^{6}$

The decomposition of elasticity into its within-year and between-year components also points to a difference between the role of credit markets and stock markets. Credit markets appear to be more important for between-year allocation, while stock markets appear to be more important for within-year allocation. Why this should be the case is not obvious. Perhaps the signaling function of stock prices is especially useful for distinguishing between firms at a given point in time.

\subsection{Mechanisms by which financial markets improve capital allocation}

How do financial markets improve the allocation of capital? The theories outlined earlier point to channels that emphasize how financial markets facilitate the identification of good investments as well as the incentives to pursue them. In this subsection I attempt to give a broad evaluation of some of these ideas. The results must be viewed with some caution because, due to data availability, the number of countries in the sample is sometimes less than two dozen. But it is reassuring that they are generally in line with theoretical predictions.

The most frequently cited social function of stock prices is to provide public signals of investment opportunities. If stock prices are uninformative they will not be useful for this purpose. Morck et al. (2000) argue that their synchronicity measure is inversely related to the amount of firm-specific information impounded into stock prices, with more firm-specific information being associated with less synchronicity. Specification (1) of Table 5 shows that $S Y N C H$ is indeed strongly negatively associated with the basic capital allocation measure. The magnitude of this effect is large: a one standard deviation increase in $S Y N C H$ is associated with a 0.137 decrease in the elasticity estimate, about half of one standard deviation. This provides some evidence that stock market prices are useful guides to investment and not entirely an economic sideshow.

Another way financial markets can improve capital allocation is by association with institutions that provide managers with good incentives. Even if it is clear which investments ought to be undertaken to maximize value, managers can choose not to pursue them. Two factors that are relevant here are state ownership and the legal rights of minority investors. State-owned firms often have political considerations, not efficiency, as the primary determinant of allocation policy. Similarly, if legal protections of minority investors are inadequate, corporate insiders are free to invest in ways that do not maximize value.

\footnotetext{
${ }^{6}$ That is, for each country, $\hat{\eta}_{c}=m_{c} \hat{\eta}_{c}^{b}+\left(1-m_{c}\right) \hat{\eta}_{c}^{w}$. The average $m$ is .543 .
} 
क् 至.

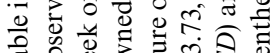

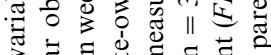

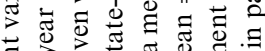

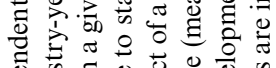

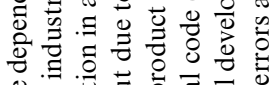
on

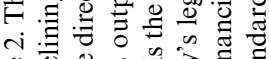

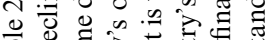

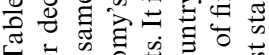

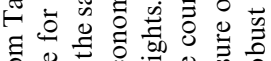

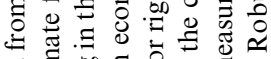

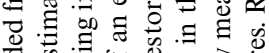

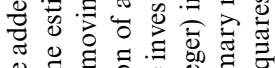

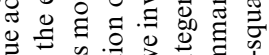

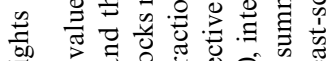
势

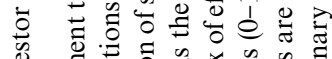

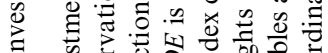
目 要

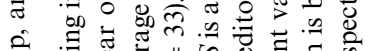
敦 然

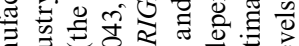

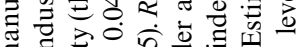

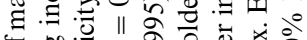
응

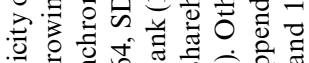

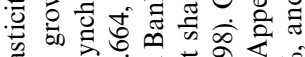
空

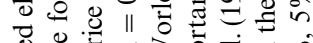

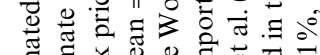

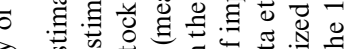

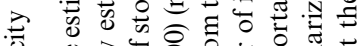

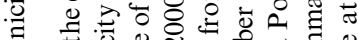

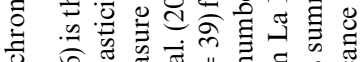
은 要

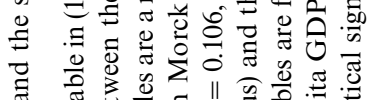

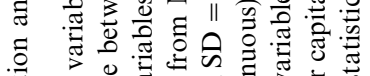

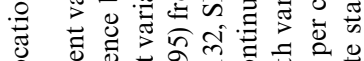

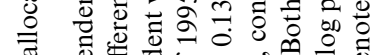
的政

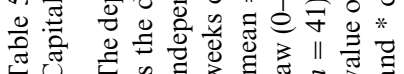


Both of these variables, RIGHTS and SOE, are associated with capital allocation in the expected direction, as indicated by specifications (2) and (3) in Table 5. According to these estimates, the influence of a one standard deviation change in these variables is roughly comparable to a similar-size change in $S Y N C H$.

When these three variables are considered jointly and also with financial development and per capita GDP, their individual effects tend to diminish, though the negative effect of synchronicity remains statistically significant. These results are reported in specifications (4)-(6). Unfortunately, due to data availability, these regressions include only a third of the full sample, so it could be misleading to conclude too much from them. The strongest statement to make here is that each variable is significantly correlated with the measured efficiency of capital allocation in the direction of theoretical priors.

The last two specifications in Table 5 address whether some countries are particularly effective at increasing investment in growing industries and/or keeping investment out of declining industries. Jensen's (1986) free cash flow theory, which emphasizes the potential for overinvestment in declining industries, seems particularly relevant here. To shed light on this issue, I consider the difference between the elasticity estimated from declining observations and that estimated from growing observations. It is indeed the case that investor rights are associated with a differential ability to keep investment from declining industries. This could reflect the greater ability of minority investors to exert pressure to invest efficiently in countries where their rights are protected, pressure that limits the inefficient reinvestment of free cash flow.

Taken as a whole, the results in Table 5 validate some important but heretofore untested intuitions about how financial markets improve the allocation of capital. While the results are subject to the usual qualifications inherent in cross-country analysis, such as small sample size and coarse data and definitions, they are consistent with several widely-held priors. One way to improve on these cross-country results might be to examine within-country changes in the allocation of capital over time, such as before and after a privatization wave or stock exchange opening. However, it is difficult to imagine within-country variation in financial development that would approach the enormous cross-country variation studied here.

\section{Conclusions}

This paper explores international differences in the efficiency of capital allocation and finds that financial market variables help to explain these differences. Relative to countries with small financial markets, financially developed countries boost investment more in their growing industries and cut it more in their declining industries. Thus, this paper identifies a specific mechanism by which financial markets improve the real economy. 
The results also shed light on some of the channels through which financial markets improve capital allocation. Stock markets, particularly those that exhibit a high proportion of firm-specific price movements, appear to provide useful public signals of investment opportunities; state-owned firms do not allocate capital efficiently; and minority investor rights appear to curb overinvestment in declining industries, consistent with Jensen's (1986) free cash flow theory. In sum, financial markets and associated institutions improve the allocation of capital through several channels. Which ones are most important, and whether capital allocation can be improved by competition or policy, are important and unanswered questions.

\section{Appendix A. Summary statistics of financial development}

Summary statistics of measures of financial development for 65 non-socialist countries. Financial development is computed as the sum of stock market capitalization to GDP and private and nonfinancial public domestic credit to GDP. (The components are averaged over 1980, 1985, and 1990 values, or as available.) The capitalization of stock markets is from the International Finance Corporation's Emerging Stock Markets Factbook, and domestic credit is from the International Financial Statistics Yearbook. The size of the credit market is the sum of lines $32 \mathrm{c}$ and $32 \mathrm{~d}$ (claims on the private sector and claims on the nonfinancial public sector; these are items in the "Domestic Monetary Survey" category) and lines 52c and 52d as available (items in the "Financial Survey" category), or 42c and 42d (items in the "Other Financial Institutions" category) where 52c and 52d are not available. GDP is the 1960 value of per capita GDP, in thousands of 1960 dollars, from the Penn World Tables version 5.6 (Summers and Heston, 1991).

\begin{tabular}{|c|c|c|c|c|}
\hline & $\begin{array}{c}\text { Financial } \\
\text { development, } \\
\text { 1980-1990 }\end{array}$ & $\begin{array}{c}\text { Stock market } \\
\text { cap. to GDP, } \\
1980-1990\end{array}$ & $\begin{array}{l}\text { Credit claims to } \\
\text { GDP, 1980-1990 }\end{array}$ & $\begin{array}{l}\text { Per capita } \\
\text { GDP, } 1960 \\
\quad(\$ 000)\end{array}$ \\
\hline Country & $\begin{aligned} & {\left[F D_{c}\right.} \\
= & \ln (1+.)]\end{aligned}$ & $\begin{array}{l}{\left[S T K / G D P_{c}\right.} \\
=\ln (1+.)]\end{array}$ & $\begin{array}{l}{\left[C R E D / G D P_{c}\right.} \\
\quad=\ln (1+.)]\end{array}$ & $\begin{array}{l}{\left[G D P_{c}\right.} \\
=\ln (.)]\end{array}$ \\
\hline Australia & 0.80 & 0.36 & 0.44 & 7.75 \\
\hline Austria & 0.86 & 0.09 & 0.77 & 5.14 \\
\hline Bangladesh & 0.21 & 0.01 & 0.20 & 0.94 \\
\hline Barbados & 0.45 & 0.06 & 0.39 & 2.64 \\
\hline Belgium & 0.55 & 0.23 & 0.32 & 5.47 \\
\hline Bolivia & 0.17 & 0.00 & 0.17 & 1.13 \\
\hline Cameroon & 0.31 & 0.00 & 0.31 & 0.63 \\
\hline Canada & 1.23 & 0.43 & 0.80 & 7.24 \\
\hline Chile & 0.85 & 0.31 & 0.54 & 2.90 \\
\hline Colombia & 0.33 & 0.03 & 0.30 & 1.69 \\
\hline
\end{tabular}


Appendix (continued)

\begin{tabular}{|c|c|c|c|c|}
\hline Country & 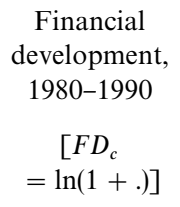 & $\begin{array}{c}\text { Stock market } \\
\text { cap. to GDP, } \\
1980-1990 \\
{\left[S T K / G D P_{c}\right.} \\
=\ln (1+.)]\end{array}$ & $\begin{array}{l}{\left[C R E D / G D P_{c}\right.} \\
\quad=\ln (1+.)]\end{array}$ & $\begin{array}{c}\text { Per capita } \\
\text { GDP, } 1960 \\
\quad(\$ 000) \\
{\left[G D P_{c}\right.} \\
=\ln (.)]\end{array}$ \\
\hline Cyprus & 0.91 & 0.14 & 0.77 & 2.08 \\
\hline Denmark & 0.72 & 0.21 & 0.51 & 6.73 \\
\hline Ecuador & 0.24 & 0.03 & 0.21 & 1.46 \\
\hline Egypt & 0.72 & 0.04 & 0.68 & 0.80 \\
\hline El Salvador & 0.31 & 0.00 & 0.31 & 1.43 \\
\hline Ethiopia & 0.24 & 0.00 & 0.24 & 0.26 \\
\hline Fiji & 0.29 & 0.00 & 0.29 & 2.11 \\
\hline Finland & 0.81 & 0.11 & 0.70 & 5.28 \\
\hline France & 1.06 & 0.17 & 0.89 & 5.82 \\
\hline Germany & 1.22 & 0.21 & 1.01 & 6.57 \\
\hline Greece & 0.67 & 0.11 & 0.56 & 2.09 \\
\hline Guatemala & 0.17 & 0.00 & 0.17 & 1.66 \\
\hline Hong Kong & $\cdot$ & 1.21 & $\cdot$ & 2.23 \\
\hline India & 0.36 & 0.08 & 0.28 & 0.77 \\
\hline Indonesia & 0.28 & 0.03 & 0.25 & 0.64 \\
\hline Iran & 0.79 & 0.04 & 0.75 & 2.99 \\
\hline Ireland & 1.42 & 0.72 & 0.70 & 3.30 \\
\hline Israel & 0.71 & 0.23 & 0.48 & 3.45 \\
\hline Italy & 0.69 & 0.11 & 0.58 & 4.58 \\
\hline Japan & 2.67 & 0.67 & 2.00 & 2.94 \\
\hline Jordan & 1.19 & 0.46 & 0.73 & 1.16 \\
\hline Kenya & 0.34 & 0.02 & 0.32 & 0.65 \\
\hline Korea (South) & 0.98 & 0.20 & 0.78 & 0.90 \\
\hline Kuwait & 1.20 & 0.49 & 0.71 & $\cdot$ \\
\hline Libya & 0.20 & 0.00 & 0.20 & . \\
\hline Macao & $\cdot$ & 0.00 & $\cdot$ & $\cdot$ \\
\hline Malawi & 0.17 & 0.00 & 0.17 & 0.38 \\
\hline Malaysia & 1.44 & 0.72 & 0.72 & 1.41 \\
\hline Malta & 0.58 & 0.00 & 0.58 & 1.38 \\
\hline Mexico & 0.29 & 0.07 & 0.22 & 2.83 \\
\hline Morocco & 0.34 & 0.03 & 0.31 & 0.83 \\
\hline Netherlands & 1.56 & 0.39 & 1.17 & 6.09 \\
\hline New Zealand & 0.79 & 0.30 & 0.49 & 7.95 \\
\hline Nigeria & 0.16 & 0.03 & 0.13 & 0.56 \\
\hline Norway & 1.11 & 0.15 & 0.96 & 5.59 \\
\hline Pakistan & 0.32 & 0.05 & 0.27 & 0.64 \\
\hline Panama & 0.57 & 0.01 & 0.56 & 1.57 \\
\hline Peru & 0.13 & 0.04 & 0.09 & 2.03 \\
\hline
\end{tabular}


Appendix (continued)

\begin{tabular}{|c|c|c|c|c|}
\hline & $\begin{array}{c}\text { Financial } \\
\text { development, } \\
1980-1990\end{array}$ & $\begin{array}{c}\text { Stock market } \\
\text { cap. to GDP, } \\
1980-1990\end{array}$ & $\begin{array}{l}\text { Credit claims to } \\
\text { GDP, 1980-1990 }\end{array}$ & $\begin{array}{c}\text { Per capita } \\
\text { GDP, } 1960 \\
\quad(\$ 000)\end{array}$ \\
\hline Country & $\begin{aligned} & {\left[F D_{c}\right.} \\
= & \ln (1+.)]\end{aligned}$ & $\begin{array}{r}{\left[S T K / G D P_{c}\right.} \\
=\ln (1+.)]\end{array}$ & $\begin{array}{l}{\left[C R E D / G D P_{c}\right.} \\
\quad=\ln (1+.)]\end{array}$ & $\begin{array}{l}{\left[G D P_{c}\right.} \\
=\ln (.)]\end{array}$ \\
\hline Philippines & 0.40 & 0.09 & 0.31 & 1.13 \\
\hline Portugal & 0.82 & 0.06 & 0.76 & 1.86 \\
\hline Singapore & 2.26 & 1.23 & 1.03 & 1.63 \\
\hline Spain & 0.90 & 0.14 & 0.76 & 3.13 \\
\hline Sri Lanka & 0.31 & 0.09 & 0.24 & 1.25 \\
\hline Swaziland & 0.20 & 0.00 & 0.20 & 1.24 \\
\hline Sweden & 1.43 & 0.29 & 1.14 & 7.57 \\
\hline Tanzania & 0.07 & 0.00 & 0.07 & 0.32 \\
\hline Trinidad \& Tobago & 0.58 & 0.12 & 0.46 & 5.62 \\
\hline Tunisia & 0.97 & 0.05 & 0.92 & 1.10 \\
\hline Turkey & 0.26 & 0.07 & 0.19 & 1.62 \\
\hline United Kingdom & 1.36 & 0.66 & 0.70 & 6.81 \\
\hline United States & 1.44 & 0.56 & 0.88 & 9.91 \\
\hline Uruguay & 0.41 & 0.00 & 0.41 & 3.96 \\
\hline Venezuela & 0.49 & 0.08 & 0.41 & 6.31 \\
\hline Zambia & 0.12 & 0.00 & 0.12 & 0.95 \\
\hline Zimbabwe & 0.53 & 0.23 & 0.30 & 1.00 \\
\hline Mean & 0.71 & 0.19 & 0.52 & 2.94 \\
\hline SD & 0.52 & 0.27 & 0.34 & 2.44 \\
\hline Mean $[\ln (1+)]$. & 0.49 & 0.15 & 0.40 & Not used \\
\hline $\mathrm{SD}[\ln (1+()]$. & 0.28 & 0.19 & 0.21 & Not used \\
\hline Mean $[\ln ()]$. & Not used & Not used & Not used & 0.71 \\
\hline $\mathrm{SD}[\ln ()]$. & Not used & Not used & Not used & 0.90 \\
\hline
\end{tabular}

\section{References}

Bagehot, W., 1873. Lombard Street: A Description of the Money Market (1962 ed.). Irwin, Homewood, IL.

Beck, T., Levine, R., Loayza, N., 2000. Finance and the sources of growth. Journal of Financial Economics 58.

Boyd, J., Prescott, E., 1986. Financial intermediary coalitions. Journal of Economic Theory 38, 211-232.

Capoglu, G., undated. The effect of financial liberalization on the efficiency of the Turkish financial system: 1980-1988. Mimeograph. Bilkent University, Ankara, Turkey.

Carlin, W., Mayer, C., 1998. Finance, investment and growth. Unpublished working paper. University College, London. 
Cho, Y., 1988. The effect of financial liberalization on the efficiency of credit allocation: some evidence for Korea. Journal of Development Economics 29, 101-110.

Demirguc-Kunt, A., Maksimovic, V., 1998. Law, finance, and firm growth. Journal of Finance 53, 2107-2137.

Diamond, D., 1984. Financial intermediation and delegated monitoring. Review of Economic Studies 51, 393-414.

Fazzari, S., Hubbard, R., Petersen, B., 1988. Financing constraints and corporate investment. Brookings Papers on Economic Activity 1, 141-206.

Fitzgerald, R., Stickler, A., Watts, T., 1979. International Survey of Accounting Principles and Reporting Practices. Price Waterhouse International, Butterworths, Ontario.

Goldsmith, R., 1969. Financial Structure and Development. Yale University Press, New Haven, CT.

Greenwood, J., Jovanovic, B., 1990. Financial development, growth, and the distribution of income. Journal of Political Economy 98, 1076-1107.

Gupta, K., Lensink, R., 1996. Financial Liberalization \& Investment. Routledge, London.

Hall, R., 1977. Investment, interest rates, and the effects of stabilization policies. Brookings Papers on Economic Activity 1:1977, 61-103.

Henry, P., 2000. Stock market liberalization, economic reform, and emerging market equity prices. Journal of Finance 55, 529-564.

Hubbard, R., 1998. Capital-market imperfections and investment. Journal of Economic Literature $36,193-225$.

Jayaratne, J., Strahan, P., 1996. The finance-growth nexus: Evidence from bank branch deregulation. Quarterly Journal of Economics 111, 639-670.

Jensen, M., 1986. Agency costs of free cash flow, corporate finance and takeovers. American Economic Review 76, 323-329.

Keynes, J.M., 1936. The General Theory of Employment, Interest, and Money. Harcourt Brace, New York.

King, R., Levine, R., 1993. Finance and growth: Schumpeter might be right. Quarterly Journal of Economics 108, 717-737.

La Porta, R., Lopez-de-Silanes, F., Shleifer, A., Vishny, R., 1997. Legal determinants of external finance. Journal of Finance 52, 1131-1150.

La Porta, R., Lopez-de-Silanes, F., Shleifer, A., Vishny, R., 1998. Law and finance. Journal of Political Economy 106, 1113-1155.

Levine, R., 1997. Financial development and economic growth. Journal of Economic Literature 35, 688-726.

Levine, R., 1998. The legal environment, banks, and long-run economic growth. Journal of Money, Credit and Banking 30, 596-613.

Levine, R., Zervos, S., 1998. Stock markets, banks, and economic growth. American Economic Review 88, 537-558.

Mayer, T., 1960. Plant and equipment lead times. Journal of Business 33, 127-132.

McKinnon, R., 1973. Money and Capital in Economic Development. Brookings, Washington, D.C.

Morck, R., Yeung, B., Yu, W., 2000. The information content of stock markets: Why do emerging markets have synchronous stock price movements? Journal of Financial Economics 58.

Rajan, R., Zingales, L., 1998. Financial dependence and growth. American Economic Review 88, 559-586.

Schumpeter, J.A., 1912. Theorie der Wirtschaftlichen Entwicklung [The theory of economic development] (1934 trans. Edition). Harvard University Press, Cambridge, MA.

Schwert, G.W., Seguin, P., 1993. Securities transaction taxes: An overview of costs, benefits and unresolved questions. Financial Analysts Journal 49, 27-35.

Shaw, E., 1973. Financial Deepening in Economic Development. Brookings, Washington, DC.

Shleifer, A., 1998. State versus private ownership. Journal of Economic Perspectives 12, 133-150. 
Summers, L., Summers, V., 1989. When financial markets work too well: A cautious case for a securities transaction tax. Journal of Financial Services Research 3, 261-286.

Summers, R., Heston, A., 1991. The Penn World Tables (Mark 5): An expanded set of international comparisons, 1950-1988. Quarterly Journal of Economics 106, 327-368.

United Nations Statistical Office, 1983. International recommendations for industrial statistics. Statistical Papers Series M, No. 48, Revision 1. United Nations, New York.

U.S. Department of Commerce, 1979. Correlation between the United States and International Standard Industrial Classifications. Technical Paper no. 1.

World Bank, 1995. Bureaucrats in Business: The Economics and Politics of Government Ownership. Oxford University Press, Oxford. 